\section{VAT Gap Dependence and Fiscal Administration Measures}

\section{Tomaž Lešnik ${ }^{1}$}

Financial Administration of the Republic of Slovenia, Slovenia

tomaz.lesnik@gov.si

\section{Timotej Jagrič}

University of Maribor, Faculty of Economics and Business, Slovenia timotej.jagric@um.si

\section{Vita Jagrič}

University of Maribor, Faculty of Economics and Business, Slovenia vita.jagric@um.si

\begin{abstract}
The paper examines the VAT gap estimated on the basis of VAT tax returns. The assessment of tax gap dependence is examined based on macroeconomic influences and the measures of the Slovenian fiscal administration. Regarding the latter, the number of audits being performed and the effects of audit activity (tax yield) have been considered. The results of the analysis support the thesis that the tax gap is reduced in conditions of economic growth. The fiscal administration measures showed the desired effect. An important factor lowering the gap was proven to be the number of (VAT) audits. A similar impact on the tax gap, although considerably smaller, was found to have effects of an audit. Audit planning might be considered as guidance for fiscal policies to lower the tax gap.
\end{abstract}

Key words: tax gap, VAT, tax gap dependence

\section{Introduction}

Tax noncompliance appears in different forms. The best known is the nonpayment of tax obligations on the basis of tax returns being filed arising as tax debt. The latter is considered to be a relatively restricted form of tax noncompliance. Less known, but much broader, is the tax gap, which is the larger aspect of tax noncompliance defined as the difference between the taxes that could potentially be collected $^{2}$ and the actual tax receipts.

The OECD (2008, p. 15) defines the gross and net tax gap; the gross tax gap can be seen as having three components:

“1) Filing noncompliance (failure to file a tax return): The dollar amount of taxes not paid in time on delinquent and nonfiled returns.

\footnotetext{
1 The views and opinions expressed in this article are those of the author and do not necessarily reflect the opinion of the Financial Administration of the Republic of Slovenia.

2 Similarly, OECD (2008, p.14) defines it as the »amount of tax that taxpayers should pay under the law « or as stated by TGPG (2016, p. 42) »theoretically collectable based on the applicable tax law (i.e., including exemptions and lower rates).«
}

ORIGINAL SCIENTIFIC PAPER

RECEIVED: MARCH 2018

REVISED: MAY 2018

ACCEPTED: MAY 2018

DOI: 10.2478/ngoe-2018-0011

UDK: 336.22:3.075.52

JEL: H26, H3O

Citation: Lešnik, T., Jagrič, T., \& Jagrič, V. (2018). VAT Gap Dependence and

Fiscal Administration Measures. Naše gospodarstvo/Our Economy, 64(2), 43-51. DOI: 10.2478/ngoe-2018-0011

\section{NG OE}

NAŠE GOSPODARSTVO OUR ECONOMY

Vol. 64 No. 22018

рр. $43-51$ 
(1) Reporting noncompliance (understating income or overclaiming tax deductions and credits): The total tax that should be reported on a promptly filed return minus the total tax actually reported on those returns.

(2) Payment noncompliance (failure to fully pay the reported taxes owed): This is the difference between the total tax liability actually reported on promptly-filed returns and the total amount of timely payments associated with those reported liabilities.”

Tax debt is connected with tax noncompliance under three of the above-mentioned definitions. The difference between tax debt and the tax gap is not only in terms of content but also in the manner of recording. While the tax debt is measurable, the accountancy category of the tax gap can only be estimated (Lešnik, 2014).

Because there is no common definition of a tax gap, consequently, methodologies for estimating it differ (Fiscalis Risk Management Platform Group, 2013). The two main methodologies are top-down and bottom-up (OECD, 2017, p. 182). Estimating VAT gaps gains importance in the European Union (EU) in order to fight against the increasing tax fraud, as it indicates the size of potential VAT evasion, although it also includes nonfraudulent nonpayments as the insolvency. Besides fraudulent or defaulted taxpayers, the VAT gap arises also from inefficiency of the tax authorities (Zidkova, 2014; OECD, 2017, p. 184). Besides the size of the VAT gap, it is of great importance to learn the factors that influence the VAT gap in order to change the VAT policy in a way that would reduce the gap (Zidkova, 2014).

While there is extensive literature about different methods of tax gap estimation (e.g., IMF 2013, IMF 2014, CASE 2013, HM Revenue \& Customs 2013, Tax Gap Project Group 2016, and others), we were only able to find a few studies that empirically assess the tax gap dependence (e.g., Reckon, 2009; CASE, 2013; Zidkova, 2014). Although theoretical research lists different factors with regard to the impact on the level of tax gap, there is a distinct lack in the empirical confirmation of such factors, especially with respect to the fiscal administration measures.

While for Slovenia, the Statistical Office of the Republic of Slovenia (SURS) estimates the VAT gap on the basis of national accounts data (SURS 2013), which is a top-down approach; in this study, we use a bottom-up approach. Our analysis gives an econometric explanation of VAT gap dependence on some relevant factors with an emphasis on the Slovenian fiscal administration measures (FURS).

First, the literature review is presented. In the third section, the used methodology of a bottom-up approach is presented together with our estimations on the VAT gap for the period
2010-2013. In the fourth section, we present the model of VAT gap dependence, where we applied our estimations on VAT gap. In addition, the results of the model, discussion, and concluding remarks are given.

\section{Literature Review}

Reckon (2009) studied the VAT gap estimations for EU member states. Broad studies on tax gaps have been conducted by the Centre for Social and Economic Research (CASE) and The Netherlands Bureau for Economic Policy Analysis (CPB) in 2013, presented the VAT gap estimations for EU member states for the 2001-2011 period. The estimations were obtained with the top-down method on the national accounts data. A final report with the VAT gap estimates for the period 2010-2014 was published in 2016 (CASE, 2016). Also the International Monetary Fund (IMF) prepares VAT gap estimations within its assistance program for the tax gap. Some examples of the IMF VAT gap estimations are estimations for the United Kingdom (IMF, 2013), Estonia (IMF, 2014), and Uganda (IMF, 2014), where a sophisticated model for the estimation of the potential VAT revenue was applied. ${ }^{3}$ The methodology used might be numbered among the top-down methods.

Bottom-up methods rely on data on individual taxpayers (by means of surveys, audits, or enquiries into randomly selected taxpayers) provide an estimate for the tax gap (Fiscalis Risk Management Platform Group, 2013; OECD, 2017, p. 183). Well known is the method on random audits data where the effects from random audits are generalized to the whole population of taxpayers. The basic presumptions are the random nature of the audit selections and the forming of the sample, which should be precise and should reflect the nature of the entire taxpayer population. A detailed methodology description can be found in HM Revenue \& Customs (2013), Swedish National Tax Agency (2008), and Danish Tax and Customs Administration (2010). In the study by the Tax Gap Project Group (2016), an overview of different methods for assessing the VAT gaps applied by member states is given.

Many studies have examined proxies for noncompliance that are less reliable or much smaller than the top-down estimates of the VAT gap based on national accounts data, performed by CASE (CASE, 2013). Agha and Haughton (1996, cit. in CASE, 2013) found in a study of 17 OECD countries in 1987 that noncompliance was higher in countries with higher standard VAT rates, and those with more departures from uniform taxation. Christie and Holzner

3 See also Heather Whicker's comment in OECD (2017), p. 181-187. 
(2006, cit. in CASE, 2013) suggest a proxy for the level of tax enforcement in a country because they found that lower compliance is associated with higher rates of VAT and with lower levels of judicial and legal effectiveness. Besides, their results suggest that compliance is positively correlated with the share of tourism in GDP.

Instead of measures of VAT noncompliance, other studies have examined empirical determinants of VAT revenues (CASE, 2013). Aizenman and Jinjirak (2008, cit. in CASE, 2013) found in a study of 44 countries that the VAT revenue ratio is positively associated with a country's openness to trade. Matthews (2003, cit. in CASE, 2013) in a study of 14 EU members found that the base-eroding effects of a tax rate increase are strong.

Reckon (2009) noted that an important explanatory variable with a statistically significant influence on VAT gaps was the corruption perception index (CPI) and the position of the legal institutions in the country. A more detailed overview was provided by the CASE (2013) study with an econometric analysis that regressed the calculated VAT gaps as a percentage of theoretical liability on a number of explanatory variables, across EU countries. The key explanatory variables in the analysis are (CASE, 2013, p. 93): the output gap, defined as the percentage difference between GDP and its long-run trend component, as estimated by official sources and the standard rate of VAT, to measure the potential gains to VAT evasion. All specifications included additional control variables (CASE, 2013, p. 94): The CPI compiled by Transparency International, to control the effect of public sector corruption; an indicator for years following the accession of the country to the EU; the logarithm of real GDP per capita, to capture the changes in economic activity. Zidkova (2014) applied a regression analysis of potential variables explaining the VAT gap for 24 EU member states in two selected years (2002 and 2006). Two factors common for both examined years that affected the VAT gap in the surveyed countries were found, namely, the final consumption of households and nonprofit organizations in each state, which had a positive impact on the VAT gap, and the share of VAT in GDP, which reduced the VAT gap. Other identified variables that would explain the size of the VAT gap were the share of the shadow economy and the standard VAT rate, with a positive impact, and GDP per capita, the share in intra-community trade, final consumption of restaurant and hotel services, and the number of VAT rates, all having a negative impact on the VAT gap.

\section{Methodology of the VAT Gap Estimation and the Estimation for the 2010-2013 Period}

One way of estimating the VAT gap with a bottom-up approach is the application of the data on VAT returns being filed. The Estonian Tax and Customs Board developed a VAT gap estimation on the basis of nonviable value-added margins declared by taxpayers in their VAT returns (IMF 2014). This methodology was described in detail within the Tax Gap Project Group report on tax gaps (2016). We used the described approach to Slovenian case.

The applied methodology is founded on the comparison between the sum of turnover (sales) and the sum of purchases on the basis of VAT returns within a one year's period. Namely, a business subject (taxpayer) should create a positive difference between the turnover and the purchases (the added value in terms of the data on VAT returns). The problem is in determining the theoretical added value, which indicates the (theoretically defined) excess of turnover over purchases and presents an important factor in VAT gap estimation. The more accurate comparison ${ }^{4}$ between turnover and purchases (the added value) with respect to different economic sectors in Slovenia has shown that the average added value could also include negative values (power and gas supply, financial and insurance activities, public administration and defence and obligatory social security contributions). While this negative relationship reflects the particularities in respective sectors, the average added values regarding other economic sectors amount to values that are between $10 \%$ and up to $200 \%$ (e.g., health and social care). We have decided, for the sake of simplicity, to apply the uniform theoretical added value in amount of $10 \%$ equally for all sectors. Thus, taxpayers are expected to declare turnover in their VAT returns that exceed purchases by at least $10 \%$. We believe that the respective theoretical added value can be the object of discussion; however, the $10 \%$ number is rather conservative. Certainly there is a possibility that purchases exceed turnover within a certain period. However, such a relationship cannot be valid over a longer period of time. In our opinion, the one-year period constitutes an appropriate time period for the consolidation of the expected business course, which should reflect in the VAT returns being filed, as well.

Before performing the estimation we considered the following issues ${ }^{5}$ :

\section{(1) Excluded were}

- Large taxpayers. This is because large taxpayers do not engage in tax avoidance in the way that small or medium businesses do.

- Taxpayers who registered in the VAT tax system within the year of the tax gap estimation.

\footnotetext{
4 The respective comparison was performed on the basis of VAT returns being filed.

5 Compare country report for Slovenia in Tax Gap Project Group (2016), p. 88.
} 
- Taxpayers who have a smaller possibility of VAT avoidance (municipalities, local communities, primary and high schools, gymnasiums, public institutions, etc.).

- $\quad$ Taxpayers in insolvency proceedings because such taxpayers do not achieve the expected relation between turnover and purchases.

(2) The comparison between turnover and purchases was made within a relevant time period (one year). It means that a too short period is not appropriate in this context, whereas the relation between turnover and purchases cannot be considered as relevant when the period of observation is too short. It is believed that one year is an appropriate time period for the relevant comparison of data on VAT returns.

(3) The amount of purchases was reduced for the purchasing of fixed assets and real estate. This is due to the fact that the purchase of fixed assets and real estate constitute large sums and therefore such purchases could deform the comparison between turnover and purchases.

Considering the above-mentioned presumptions, it follows ${ }^{6}$ :

$$
\begin{gathered}
V A_{t}=\sum_{t} T O_{t}-\sum_{t} P U R_{t} \\
T V A_{t}=0,1 \cdot \sum_{t} P U R_{t} \\
V A_{t} \geq T V A_{t}
\end{gathered}
$$

$V A_{t}$ - added value in the period $t$

$\sum_{t} T O_{t}-$ sum of turnovers in the period $t$

$\sum_{t} P U R_{t}$ - sum of purchases in the period $t$, while the purchase of fixed assets and real estate are excluded $T V A_{t}$ - theoretical added value in the period $t$

If

$V A_{t}<T V A_{t}$, then Tax gap $=\left(T V A_{t}-V A_{t}\right) \cdot 20 \%$.

In the above formula, $20 \%$ is taken because the general VAT rate within the period of VAT gap estimation in Slovenia was $20 \%$.

It is necessary to emphasise that, according to the OECD definition of the tax gap, our estimation refers only to reporting noncompliance (understating turnover or overclaiming purchases).

VAT gap for the 2010-2013 period is shown in Figure 1 as the share of total VAT revenues (left ordinate) and as a share

\footnotetext{
${ }^{6}$ Compare country report for Slovenia in Tax Gap Project Group (2016), p. 88.
}

in GDP of Slovenia (right ordinate). The VAT gap increased until 2012 and then declined in 2013. We believe that this course of the VAT gap could be due to the changes in the macroeconomic environment.

Figure 1. Share of VAT Gap in the VAT Revenues and in GDP (Both in \%)

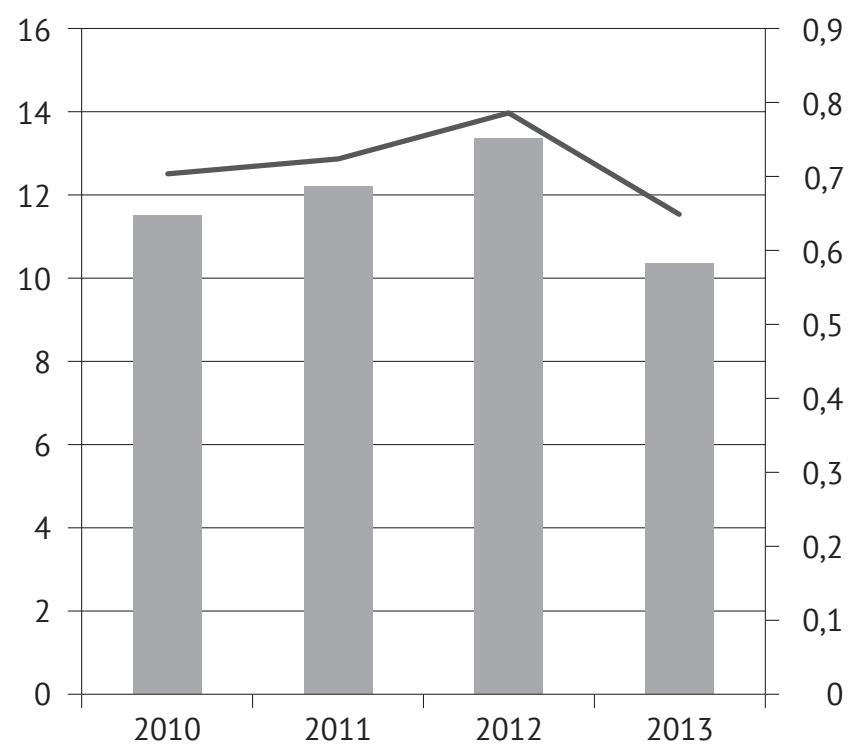

VAT gap as the share in VAT revenues

— VAT gap as the share in GDP

Source: Author's calculations

\section{Data and Methodology of the VAT Gap Dependencies}

We will use the estimates of the VAT tax gap presented in the previous section. To obtain the appropriate sample of observations regarding the VAT gap, from the aggregate VAT gap for a given year, the VAT gaps for local (regional) tax offices (TO) were calculated. Thus, we obtained a large enough sample based on the VAT gaps for 15 local TOs within the four-year time period. The VAT gaps were expressed as shares of the GDP from statistical regions. Due to the introduction of some explanatory variables in the model, which took their values according to the statistical regions (data of SURS, 2014), whereas the dependant variable got its values with regard to the territorial (regional) principle of the TO; the dependant variable was reasonably adapted to the explanatory variables on the basis of statistical regions. With respect to the available data, a regression analysis of the VAT gap dependence from the following categories was applied:

1.) The changes in the macroeconomic environment

2.) The fiscal administration (FURS) measures

3.) The VAT gap from the previous period (year)

4.) The regional differences 
Table 1. Statistical Properties of Selected Data

\begin{tabular}{|c|c|c|c|c|c|c|c|c|}
\hline & GAP & GAP_LAG & GDP & AUD_NUM_LAG & AUD_YIE & D1 & D2 & AUD_YIE_LAG \\
\hline Mean & 0.446832 & 0.443410 & 96.39433 & 19.42613 & 141.2450 & 0.066667 & 0.066667 & 36.15249 \\
\hline Median & 0.359391 & 0.385738 & 96.54493 & 18.81537 & 92.30605 & 0.000000 & 0.000000 & 36.92460 \\
\hline Maximum & 1.163698 & 1.163698 & 100.8120 & 44.69274 & 445.5732 & 1.000000 & 1.000000 & 64.11725 \\
\hline Minimum & 0.018522 & 0.023365 & 90.54568 & 6.392694 & 16.07097 & 0.000000 & 0.000000 & 3.974721 \\
\hline Std. Dev. & 0.324256 & 0.304543 & 2.568748 & 7.071129 & 104.9936 & 0.253708 & 0.253708 & 17.24759 \\
\hline Skewness & 0.741743 & 0.733997 & -0.322341 & 1.426265 & 1.261429 & 3.474396 & 3.474396 & -0.028758 \\
\hline Kurtosis & 2.731212 & 2.885233 & 2.620020 & 6.912546 & 3.914258 & 13.07143 & 13.07143 & 2.102369 \\
\hline Jarque-Bera & 2.841224 & 2.710219 & 0.700001 & 29.30618 & 9.000856 & 187.1492 & 187.1492 & 1.011312 \\
\hline Probability & 0.241566 & 0.257919 & 0.704688 & 0.000000 & 0.011104 & 0.000000 & 0.000000 & 0.603110 \\
\hline Sum & 13.40496 & 13.30231 & 2891.830 & 582.7839 & 4237.350 & 2.000000 & 2.000000 & 1084.575 \\
\hline Sum Sq. Dev. & 3.049116 & 2.689639 & 191.3555 & 1450.025 & 319685.8 & 1.866667 & 1.866667 & 8626.903 \\
\hline Observations & 30 & 30 & 30 & 30 & 30 & 30 & 30 & 30 \\
\hline
\end{tabular}

Source: Author's calculations

As a macroeconomic variable, the data on GDP per capita by individual statistical region was applied, while the nominal values were deflated by the consumer price index, and yearly changes of deflated data were calculated. Also, as an explanatory variable, the VAT gap from the previous year was introduced. With regard to FURS measures, the data on the number of audits being performed with respect to the VAT area as the share of the total number of audits being performed were applied, as well as the yield (effects) from audit activities with respect to the VAT area as the share of the total audit yield. In connection with both of the FURS measures, the lagged variables were also tested as well as the dummy variables regarding the regional differences.

A cross-section model with the following specifications was formed:

$G A P_{t, i}=\beta_{0}+\beta_{1} G A P \_L A G_{t, i}+\beta_{2} G D P_{t, i}+$

$+\beta_{3} A U D \_N U M \_L A G_{t, i}+\beta_{4} A U D \_Y I E_{t, i}+$

$+\beta_{5} A U D \_Y I E \_L A G_{t, i}+\beta_{6} D 1_{t, i}+\beta_{7} D 2_{t, i}+u_{t, i}$,

where GAP stands for the VAT gaps of a local TO as the share in GDP by individual statistical region, GAP_LAG stands for the VAT gaps of a local TO as the share in GDP by individual statistical region as a lagged variable, GDP captures the yearly changes of GDP per capita by individual statistical region, AUD_NUM_LAG stands for the ratios of "the number of audits being performed with respect to the VAT area divided by the total number of audits being performed” as the lagged variable,
AUD_YIE captures the ratios of "the yield from audit activities with respect to VAT area divided by the total audit yield," AUD_YIE_LAG stands for the ratios "the yield from audit activities with respect to VAT area divided by the total audit yield" as lagged variable, $D 1$ and $D 2$ stand for dummies with respect to the two of the local TO, index $t$ stands for time, and $i$ for the local tax office. The statistical properties of the selected data are presented in Table 1.

As shown in Table 1, four out of eight time-series exhibit empirical distributions, which differ from a normal distribution (standard JB for normal distribution was applied). But, as we will see in diagnostic tests for the model, this finding did not influence the properties of the model, particularly as the dependent variable is distributed normally.

\section{Results}

The model estimation is given in Table 2. The parameters of the model were estimated using the OLS method and using White heteroskedasticity-consistent standard errors and covariance. After adjustments due to lagged variables, the sample size was 30 observations. Before we comment on the results, we will present the results of the tests that were applied in order to check the robustness of the model. We performed a Ramsey RESET test in order to check if the model was correctly specified. As we can see in Table 3, the RESET 
Table 2. Results of the Model for the Dependent Variable Gap

\begin{tabular}{|c|c|c|c|c|}
\hline Variable & Coefficient & Std. Error & t-Statistic & Prob. \\
\hline $\mathrm{C}$ & 5.889259 & 1.865374 & 3.157147 & 0.0046 \\
\hline GAP_LAG & 0.785296 & 0.114913 & 6.833805 & 0.0000 \\
\hline GDP & -0.053251 & 0.017861 & -2.981375 & 0.0069 \\
\hline AUD_NUM_LAG & -0.013084 & 0.004711 & -2.777297 & 0.0110 \\
\hline AUD_YIE & -0.001556 & 0.000531 & -2.928782 & 0.0078 \\
\hline $\mathrm{D} 1$ & -0.123199 & 0.058793 & -2.095484 & 0.0479 \\
\hline $\mathrm{D} 2$ & -0.142788 & 0.062772 & -2.274697 & 0.0330 \\
\hline AUD_YIE_LAG & -0.004590 & 0.002314 & -1.983726 & 0.0599 \\
\hline R-squared & 0.824782 & Mean dependent var & & 0.446832 \\
\hline Adjusted R-squared & 0.769031 & S.D. dependent var & & 0.324256 \\
\hline S.E. of regression & 0.155835 & Akaike info criterion & & -0.656860 \\
\hline Sum squared resid & 0.534260 & Schwarz criterion & & -0.283207 \\
\hline Log likelihood & 17.85289 & Hannan-Quinn criter. & & -0.537325 \\
\hline F-statistic & 14.79398 & & & \\
\hline Prob (F-statistic) & 0.000001 & & & \\
\hline
\end{tabular}

Source: Author's calculations

test shows no indication of any possible misspecification. This is also confirmed by the Likelihood ratio test statistic.

Table 3. Ramsey Reset Test

\begin{tabular}{lccc} 
& Value & df & Probability \\
\hline t-statistic & 0.585540 & 21 & 0.5644 \\
\hline F-statistic & 0.342857 & $(1,21)$ & 0.5644 \\
\hline Likelihood ratio & 0.485840 & 1 & 0.4858 \\
\hline
\end{tabular}

Source: Author's calculations

The correlation matrix in Table 4 indicates that a multicollinearity problem in the model isn't important. Thus, from Table 4 we can observe a strong negative correlation between the explanatory variables AUD_YIE and AUD_YIE_LAG. However, the relative correlation has no undesired impact on the results of the model.

The results of the model were in line with our expectations; we believe the model confirms the VAT gap dependence from the introduced explanatory categories. We can observe a negative regression coefficient with respect to changes of GDP per capita, which suggests that an increase in a respective variable has a negative influence on the VAT gap and vice versa. A similar relationship between the tax gap and GDP has also been established by previous studies. Both of the FURS activities were proven to be statistically significant with the negative regression coefficients, which suggests that an increase in the intensity of FURS activities

Table 4. Correlation Matrix of Explanatory Variables

\begin{tabular}{|c|c|c|c|c|c|c|c|}
\hline & GAP_LAG & GDP & AUD_NUM_LAG & AUD_YIE & D1 & D2 & AUD_YIE_LAG \\
\hline GAP_LAG & 1.000000 & & & & & & \\
\hline GDP & 0.066780 & 1.000000 & & & & & \\
\hline AUD_NUM_LAG & -0.254759 & -0.066604 & 1.000000 & & & & \\
\hline$\overline{A U D \_Y I E}$ & 0.019571 & -0.267844 & -0.166163 & 1.000000 & & & \\
\hline $\mathrm{D} 1$ & 0.084746 & -0.075144 & 0.093820 & -0.175498 & 1.000000 & & \\
\hline D2 & -0.282771 & -0.008496 & -0.178795 & 0.107595 & -0.071429 & 1.000000 & \\
\hline AUD_YIE_LAG & 0.105718 & -0.028157 & 0.172157 & -0.734576 & 0.163620 & -0.169421 & 1.000000 \\
\hline
\end{tabular}

Source: Author's calculations 
reduces the VAT gap. The two local regions (the two local TO areas) were proven as statistically significant as well. In our opinion, such a result might be explained with the sharp decline of the VAT gap as the share of GDP in 2013 with respect to both of the local TOs, whereas the respective decline was more outstanding than the average. The lagged dependant variable reveals a positive regression coefficient, which suggests that the higher VAT gap from the previous year increases the current VAT gap.

To determine the significance of the individual explanatory variable, the product of the average value of the explanatory variable and the regression coefficient was calculated for each of the explanatory variables, and the absolute values of the respective products were then compared. In terms of the most important variables, we can point to the yearly changes of the GDP per capita and the lagged dependant variable followed by the FURS measures with respect to the number of audits being performed as a lagged variable and the yield from audit activities.

\section{Discussion and Conclusions}

The presented methodology for the VAT gap estimation should be listed among the bottom-up methods. It might be considered as a useful and practical approach as well as a supplement to the methods of tax gap estimation already in existence. The main issue of the respective methodology is based on the assumption of the rational economy of taxpayers, which is to create a positive difference between turnover and purchases. Those taxpayers who do not declare at least a minimal, theoretically setting a positive difference in their VAT returns, might be considered as potential candidates for VAT gap estimation, of course while still considering the above-mentioned assumptions.

The VAT gap estimations as a result of the respective method are lower than the VAT gap estimations acquired via the top-down methods. Also, according to the OECD definition of the tax gap, the respective VAT gap comprises only a part of the entire VAT gap, namely, the lack of VAT due to the reporting noncompliance.

Review of the bottom-up methods, which are used by fiscal administrations for tax gap estimation, indicates that the random audit method and its varieties are the most commonly used. The comparison between turnover and purchases on the basis of VAT returns with respect to the VAT gap estimation might present a supplement to the existing methods of VAT gap estimation that are used by fiscal administrations. Certainly, the comparisons of tax gaps according to different estimation methods as well as the trends of tax gaps and the analyses of the causes for tax gap fluctuations are relevant.
We believe that the results of the econometric analysis of the VAT gap dependence should be considered from different aspects. Although the effects of enforcement measures (the measures of fiscal administrations, e.g., audits, fines, enforcement debt collection) on the level of tax compliance are well known and have been investigated in existing literature, there are nevertheless only a few studies that have empirically assessed the correlation between the tax gap and fiscal administration measures. Reckon (2009) and CASE (2013) assessed the correlation between VAT gap and fiscal administration measures indirectly, with the application of the CPI, which, among other factors, reflects the efficiency of the tax regime enforcement in countries. The influence of audits on tax compliance regarding VAT was studied by Bergmann and Nevarez (2006), where they investigated the differences in the net VAT obligation before and after an audit was performed. In this sense, our analysis of VAT gap dependence from the audit activities of FURS might be considered to be a contribution to studies with respect to tax compliance dependence as well as the empirical confirmation of the impact of direct fiscal administration measures as important tax gap determinants. The lower values of regression coefficients and the smaller significance regarding the FURS explanatory variables should be interpreted in connection with the method of present analysis and the applied data. Namely, the dependant variable VAT gap is expressed as the share in the GDP of an individual statistical region (local TO); thus, the data are in an aggregate form on the regional level. The explanatory variables are designed similarly, all on the aggregate level. In this aspect, the performing of an analysis of VAT gap dependence regarding the sample of individual data on taxpayers would be meaningful, as more significant influence of the explanatory variables regarding FURS measures might be expected.

The regression model of the VAT gap dependence can also be employed as a measure for the fiscal administration efficiency, where the influence of relative measures on the tax gap reduction in different time periods would be observed. In this regard, the planning of audits and the consideration of arguments for the strengthening of the fiscal administration function are possible to discuss as well. Such analysis might appear as particularly meaningful regarding the fiscal policy choices for the systematic tax gap reduction, as the costs of the tax gap reduction (e.g., with more intensive audit programmes and other verification activities) on the one hand and the expected reduction of the tax gap on the other hand would have been compared.

However, we are aware of the limitations of our research, which derive primarily from the fact that the level of tax gap cannot be exactly defined; however, there are estimations available. Moreover, in our analysis, we followed the presumption regarding the $10 \%$ theoretical difference between turnover and purchases, which is applied for the tax gap estimation, subsequently. The respective simplification 
in the analysis was applied due to the large extent of data on the basis of VAT returns being filed (more than 100,000 VAT returns are filed in a single year). The estimation of the VAT gap, when considering the actual average added values, according to individual sectors (or in some other relevant manner) would have resulted in different values of VAT gap estimation. In addition, we only observed a short period of tax gap fluctuations, whereas a relatively small number of observations was available.

The econometric explanation of VAT gap dependence is of importance as one of the first empirically established influences of direct fiscal administration measures on the VAT gap. The results of the regression model might be applied as an index of the fiscal administration efficiency as well as a tool with respect to planning the focus and intensity of audits. In addition, the relative regression model (or even more improved) might be employed as guidance for the fiscal policy choices about closing the tax gap, particularly in the sense of a cost-benefit analysis. Namely, the question is whether it is reasonable to plan the tax gap reduction with the application of enforcement measures (audits and fines), as there is an existing possibility of an excessive amount of costs from respective enforcement measures over the desired effect. The fiscal policy should consequently focus to a higher degree on all the other known determinants of the tax gap and recognize their benefits in considering the efforts for a higher level of tax compliance.

\section{References}

Bergman, M., \& Nevarez, A. (2006). Do audits enhance compliance? An empirical assessment of VAT enforcement. National Tax Journal, 59(4), 817-832. https://doi.org/10.17310/ntj.2006.4.04

Center for Social and Economic Research (CASE) \& Netherlands Bureau for Economic Policy and Analysis (2013). Study to quantify and analyse the VAT Gap in the EU-27 Member States. Retrieved from https://ec.europa.eu/taxation_customs/sites/taxation/files/docs/ body/vat-gap.pdf [23.3.2018]

Center for Social and Economic Research (CASE) \& Institute for Advanced Studies (2016). Study and Reports on the VAT Gap in the EU-28 Member States: 2016 Final Report TAXUD/2015/CC/131. A Study for the Directorate General Taxation and Customs Union. Retrieved from https://ec.europa.eu/taxation_customs/sites/taxation/files/2016-09_vat-gap-report_final.pdf [19.3.2018]

Christie, E., \& Holzner, M. (2006). What explains tax evasion? An empirical assessment based on european data. wiiw Working Papers 40.

Fiscalis Risk Management Platform Group (2013). Tax gap and compliance map report. European Commission.

HM Revenue \& Customs (2013). Methodological annex for measuring tax gaps 2013. Retrieved from https://www.gov.uk/government/ uploads/system/uploads/attachment_data/file/249541/131009_MTG_2013_Annex.pdf

International Monetary Fund (2013). United Kingdom: Technical Assistance Report - Assessment HMRCs Tax Gap Analysis. Retrieved from https://www.imf.org/external/pubs/ft/scr/2013/cr13314.pdf

International Monetary Fund (2014a). Republic of Estonia: Revenue Administration Gap Analysis Program - The Value Added-Tax Gap. Retrieved from https://www.imf.org/external/pubs/ft/scr/2014/cr14133.pdf

International Monetary Fund (2014b). Uganda: Revenue Administration Gap Analysis Program - The Value Added-Tax Gap. Retrieved from http://www.finance.go.ug/index.php?option=com_docman\&task=doc_details \&gid=397 \&ltemid=118

Lešnik, T. (2014). Davčne vrzeli - kako jih zmanjšati?, Davčno finančna praksa, XV (10), 10-12.

Mathews, K. (2003).VAT evasion and VAT avoidance: Is there a European Laffer Curve for VAT?, International Review for Applied Economics, 17 (1), 105-114. https://doi.org/10.1080/713673162

OECD (2008). Monitoring taxpayer's compliance: A practical guide based on revenue body experience. Forum on Tax Administration: Compliance Sub-group. Retrieved from http://www.oecd.org/tax/taxadministration/40947920.pdf

OECD (2017). Tax Administration 2017: Comparative Information on OECD and Other Advanced and Emerging Economies. Paris: OECD Publishing. Retrieved from http://dx.doi.org/10.1787/tax_admin-2017-en [19.3.2018]

Reckon (2009). Study to quantify and analyse the VAT gap in the EU-25 Member States. Retrieved from http://ec.europa.eu/taxation_ customs/resources/documents/taxation/tax_cooperation/combating_tax_fraud/reckon_report_sep2009.pdf

SKAT - Danish Tax and Customs Administration (2010). Business sector analysis. Compliance with tax and VAT rules by businesses in Denmark, Tax year 2006.

SURS - Statistical Office of the Republic of Slovenia (2013). Teoretični davek na dodano vrednost in podatki o davčni vrzeli. Retrieved from http://www.stat.si/doc/vsebina/03/Teoreticni\%20davek\%20na\%20dodano\%20vrednost\%202009-2010.pdf

SURS - Statistical Office of the Republic of Slovenia (2014). Data on GDP. Retrieved from http://www.stat.si/

Swedish National Tax Agency (2008). Tax GAP MAP for Sweden. How was it created and how can it be used? Retrieved from http://www. skatteverket.se/download/18.225c96e811ae46c823f800014872/Report_2008_1B.pdf

Tax Gap Project Group (2016). The concept of tax gaps, Report on VAT gap estimations. European Commission: Fiscalis Tax Gap Project Group (FPG/041). Retrieved from https://ec.europa.eu/taxation_customs/sites/taxation/files/docs/body/tgpg_report_en.pdf

Zidkova, H. (2014). Determinants of VAT gap in EU, Prague Economic Papers, 4, 514-530. https://doi.org/10.18267/j.pep.496 


\section{Authors}

Dr. Tomaž Lešnik is employed as an analyst in the Financial Administration of the Republic of Slovenia. He obtained his PhD degree from University of Maribor, Faculty of Economics and Business. His research is focused on the area of public finances, especially on the effectiveness of fiscal measures, taxes, influencing tax compliance and different aspects of fiscal administrations. He has published several scientific and professional papers.The author can be contacted at lesnik.tomaz@ amis.net.

Ddr. Timotej Jagrič is a full professor for Applied economics and econometrics and full professor for Finance at University of Maribor, Faculty of Economics and Business. He is head of Institute of Finance and Banking and is Certified in Risk Management (CRM). His current focus of research are methods in risk management and artificial intelligence.

Vita Jagrič is assistant professor at the Department of Finance and Banking at the University of Maribor in Slovenia. In 2005, she graduated in economics and in 2016 in law. She received her PhD in 2012 for her thesis of estimating probability of default for retail credit: nonlinear approach with self-organizing maps. Her research interest focuses on financial systems, financial regulation, risk management, insurance, and taxation.

\section{Odvisnost vrzeli DDV in ukrepi finančne uprave}

\section{Izvleček}

Prispevek analizira DDV-vrzel, ki je bila ocenjena na osnovi izpolnjenih davčnih napovedi za DDV. Ocena odvisnosti davčne vrzeli je analizirana na osnovi makroekonomskih vplivov in ukrepov Finančne uprave RS. V zvezi s slednjimi je upoštevano število izvedenih pregledov ter učinki aktivnosti pregledov (pobrani davek). Rezultati analize podpirajo tezo, da se davčna vrzel zmanjšuje v pogojih ekonomske rasti. Ukrepi finančne uprave so pokazali želeni učinek. Izkazalo se je, da je pomemben dejavnik zmanjševanja vrzeli prav število (DDV) pregledov. Podoben, vendar pomembno manjši učinek imajo učinki pregledov. Načrtovanje pregledov bi se lahko štelo kot smernica za fiskalno politiko s ciljem zmanjševanja davčne vrzeli.

Ključne besede: davčna vrzel, DDV, odvisnost davčne vrzeli 